\title{
Vegetation changes over palaeo-time scales in Africa
}

\author{
Daniel O. Olago* \\ Department of Geology, University of Nairobi, PO Box 30197, Nairobi, Kenya
}

\begin{abstract}
The record of palaeovegetation dynamics in Africa generally extends back to $30000 \mathrm{yr}$ $\mathrm{BP}$, and longer records, where they do exist, tend to be characterised by hiatuses, giving a broken slide-show of vegetation dynamics in the past. A few specific sites on, for example, Mount Kenya and the Burundi Highlands in the equatorial tropics offer much longer and continuous records. Pollen analysis of lake, peat, swamp sediments and other materials have largely formed the basis of vegetation and climatic reconstruction on the continent. These pollen diagrams indicate depression of highland vegetation to lower altitudes relative to their positions today, fragmentation of lowland forests, and concomitant expansion of grassland prior to $14000 \mathrm{yr}$ BP, with maximum impact occurring between 22000 and $14000 \mathrm{yr}$ BP. The period 14000 to $10000 \mathrm{yr}$ BP was a time of transition, with vegetation recovering to present-day distributions by $10000 \mathrm{yr} \mathrm{BP}$. These are generalisations, and significant differences do occur from region to region; in particular, vegetation change in southern Africa has been largely asynchronous with the rest of the African continent, save for the peak of the last glacial maximum at $18000 \mathrm{yr}$ BP. Based on the changes in vegetation, the period prior to $14000 \mathrm{yr} \mathrm{BP}$ is viewed as less humid (with exceptions in southern Africa) and cooler than present, with maximum aridity and temperature depressions (estimated to be between 4 and $7^{\circ} \mathrm{C}$ lower than today, occurring between 22000 and $14000 \mathrm{yr}$ BP. A climatic amelioration followed thereafter, reaching optimal warm and humid conditions at about $10000 \mathrm{yr} \mathrm{BP}$ in the equatorial regions, and about 2000 to $5000 \mathrm{yr}$ later in the subtropical regions. Temperature has been generally viewed as being the major factor driving climate change. Following the recent discovery, from polar ice cores, that atmospheric $\mathrm{CO}_{2}$ concentrations have also changed through time, current palaeovegetation studies have focused on both pollen and, to probe the physiological effect of changing atmospheric $\mathrm{CO}_{2}$ on vegetation, on bulk and compound-specific stable carbon isotope analysis of organic sediments. These studies have yielded much valuable information on the relationship between the climatic drivers of vegetation change, namely, temperature, precipitation and atmospheric $\mathrm{CO}_{2}$ changes. They suggest that $\mathrm{CO}_{2}$ rather than temperature was the main driving force of vegetation change in the tropics during the glacial-interglacial period, and that vegetation may have responded much more sensitively to humidity changes based on physiological responses to lowered $\mathrm{CO}_{2}$ concentrations. These conclusions are supported by modelling experiments, and indicate that previous estimates of temperature depression in the tropics are overestimated and need to be revised in light of these new discoveries.
\end{abstract}

KEY WORDS: Palaeovegetation $\cdot$ Palaeoclimate $\cdot$ Africa

Resale or republication not permitted without written consent of the publisher

\section{INTRODUCTION}

It is now evident, from the numerous palaeoclimatic and palaeoenvironmental studies that have been carried out worldwide, that the temporal climatic and environmental changes characteristic of the low lati-

*E-mail: dolago@uonbi.ac.ke tude regions during the late Quaternary and other earlier periods can be linked to a combination of earthextrinsic and earth-intrinsic climate-forcing mechanisms, e.g. changes in the orbital parameters and the resultant changes in the radiation balance and hence earth surface temperatures, changes in sea surface temperatures and ocean and atmospheric circulation patterns, high latitude meltwater inputs particularly in 
the North Atlantic, global variations in atmospheric $\mathrm{CO}_{2}$ concentrations, etc. Regional factors, such as topography and the precipitation-evaporation balance, also influence the environmental response to climate change. The relative importance of these factors which drive climate change and the extent of the linkages between them are still unclear, particularly in the low latitude regions, where there is a dearth of palaeoclimatic and palaeoenvironmental data. This paper reviews the palaeovegetation changes in Africa, and discusses earlier proposed mechanisms of change (temperature and precipitation) in the light of the relatively new data on changing atmospheric $\mathrm{CO}_{2}$ contents over geological time scales.

\section{MODERN PHYSIOGRAPHY, CLIMATE AND VEGETATION OF AFRICA}

Africa is the world's second largest continent, most of which lies below $2000 \mathrm{~m}$ save for a few highland areas, namely, the Atlas mountains, Tibesti mountains in cen-

Table 1. Principal vegetation types and characteristic pollen taxa of the major floristic zones of Africa (from Street-Perrott \& Perrott 1993, after White 1983). Zones XV (Zanzibar-Inhambane) and XVI (Tongaland-Pongaland) not discussed

\begin{tabular}{|c|c|c|}
\hline Zone & Type & Characteristic vegetation \\
\hline I & Mediterranean & $\begin{array}{l}\text { Broad-leaved sclerophyllous forest with evergreen Quercus (oak); coniferus forest with } \\
\text { Pinus (pome), Cedrus (cedar) etc., deciduous Quercus forest }\end{array}$ \\
\hline II & Pre-Saharan & $\begin{array}{l}\text { Sclerophyllous forest with Juniperus (juniper), Olea (olive), Pistacia (pistachio) and others; } \\
\text { scrub forest, bushland and shrubland; tussock grasslands (steppes) with Artemisia (sage- } \\
\text { brush), Lygeum spartum and abundant dryland taxa }\end{array}$ \\
\hline III & Saharan & $\begin{array}{l}\text { Desert; certain plants characteristic of wadis (e.g. Tamarix) and of shady, rocky, gravelly or } \\
\text { saline faces (e.g. Cornulaca, Calligonum, Fagonia); Saharomontane vegetation (Ahaggar, } \\
\text { Tibesti) includes Mediterranean/Pre-Saharan elements such as Olea laperrini, Artemisia, } \\
\text { Ephedra, Erica arborea }\end{array}$ \\
\hline IV & Sahelian & $\begin{array}{l}\text { Semi-desert grassland and thorny shrubland (north) to wooded grassland and bushland } \\
\text { (south), with Acacia spp., Commiphora africana, Balanites aegyptiaca, Euphorbiaceae, and } \\
\text { abundant dryland taxa }\end{array}$ \\
\hline $\mathrm{V}$ & Sudanian & $\begin{array}{l}\text { Woodland and dry forest, with Celtis integrifolia, Hymenocardia acida, Lannea, Prosopis } \\
\text { africana, Mytragyna inermis, etc. }\end{array}$ \\
\hline VI & Sudano-Guinean & $\begin{array}{l}\text { Mosaic of dry, peripheral, semi-evergreen rainforest and woodland or secondary grassland, } \\
\text { transitional between Zones V and VII }\end{array}$ \\
\hline VII & Guinea-Congolian & $\begin{array}{l}\text { Lowland rainforest and swamp forest with very diverse endemic flora including Chlorofora, } \\
\text { Holoptelea, Uapaca, Musanga and Elaeis guineensis (oil palm); montane rainforest and } \\
\text { grassland (above } 1000 \mathrm{~m} \text { altitude) with Olea hochstetteri, Podocarpus and Ilex }\end{array}$ \\
\hline VIII & $\begin{array}{l}\text { Lake Victoria } \\
\text { regional mosaic }\end{array}$ & $\begin{array}{l}\text { Similar to Zone VI; dry, peripheral, semi-evergreen rainforest and scrub forest with Celtis } \\
\text { spp., Holoptelea, and Rhus natalensis; wooded grassland with Acacia and palms (Borassus) }\end{array}$ \\
\hline IX & Zambezo-Congolian & Similar to Zone VI \\
\hline $\mathrm{X}$ & Somali-Masai & $\begin{array}{l}\text { Deciduous bushland and thicket similar to Zone IV, grading upward into Zone XVIII } \\
\text { through semi-evergreen to evergreen bushland and thicket with Cordia, Croton, etc. }\end{array}$ \\
\hline $\mathrm{XI}$ & Zambezian & $\begin{array}{l}\text { Dry forest and woodland (bushveld) with Brachystegia (miombo), Burkea africana, Combre- } \\
\text { taceae and Proteaceae (Protea, Faurea) }\end{array}$ \\
\hline XII & Kalahari-Highveld & $\begin{array}{l}\text { Wooded grassland and bushland (Kalahari thornveld) with Acacia spp., Caparidaceae, Tar- } \\
\text { chonantheae (Compositae) and Aloe; upland grassland (highveld) with abundant Gramineae } \\
\text { (grasses), Cyperaceae (sedges), Compositae (daisy family) and Ericaceae (heaths) }\end{array}$ \\
\hline XIII & Karoo-Namib & Semi-desert shrubland and desert; few relevant pollen data \\
\hline XIV & Cape & $\begin{array}{l}\text { Sclerophyllous shrubland (fynbos, machia) with Asteraceae, Restionaceae, Proteaceae, Eri- } \\
\text { caceae, Artemisia, Cliffortia, Myrica, Stoebe, etc. }\end{array}$ \\
\hline XVII & Afromontane & $\begin{array}{l}\text { Dry montane forest with Podocarpus, Juniperus and Olea; wet montane forest with Afrocra- } \\
\text { nia, Macaranga, Neoboutonia, Prunus, Ilex, etc.; montane veld with Celtis and Rhus (south- } \\
\text { ern Africa) }\end{array}$ \\
\hline XVIII & $\begin{array}{l}\text { Afroalpine and } \\
\text { Austroafroalpine }\end{array}$ & $\begin{array}{l}\text { Ericaceous bushland and shrubland with Cliffortia, Erica arborea, and other giant heathers } \\
\text { (lower part, eastern Africa); high altitude shrubland and grassland, similar to paramo in } \\
\text { South America, with Dendrosenecio, Lobelia, Artemisia afra, Alchemilla, and Helichrysum } \\
\text { (everlasting flowers) (upper part, eastern Africa); alpine veld with fynbos elements (Eri- } \\
\text { caceae, Passerina, Cliffortia, etc.) (southern Africa) }\end{array}$ \\
\hline
\end{tabular}


tral Sahara, Ethiopian mountains, East African mountains and the Drakensburg mountains in southern Africa. It is unique in that it sits astride the equator, and this, coupled with its relatively simple physiography, results in a more or less symmetrical distribution of climate about the equator (Thompson 1965), which is modified by regional factors such as topography and large water bodies (Thompson 1965, Ogallo 1989). As a result of its latitudinal span $\left(27^{\circ} \mathrm{N}\right.$ to $\left.34.5^{\circ} \mathrm{S}\right)$, there is a zonal distribution of climate from the meteorological equator northwards and southwards. The equatorial zone experiences the confluence of airflows from the northern and southern hemispheres, and the confluence zone migrates northward to about $15^{\circ}$ to $24^{\circ} \mathrm{N}$ in June to August, and southward to about $8^{\circ} \mathrm{N}$ to $16^{\circ} \mathrm{S}$ in December to February, giving rise to humid climate with a double rainfall maximum, flanked on the north and south by broad belts of monsoonal climates characterised by summer rains and winter drought (StreetPerrott \& Perrott 1993). The monsoonal climate belts are flanked to the north by the arid Sahara and to the south by semi-arid (e.g. Namib desert) and savannah regions. The temperate northern and southern extremities of the continent, which project into the belts of mid-latitude westerlies, experience westerly cyclonic disturbances which give rise to high winter precipitation (Street-Perrott \& Perrott 1993).

The principal controls on the distribution of vegetation in Africa (Table 1) are total annual rainfall and the timing, duration and intensity of the dry seasons (Street-Perrott \& Perrott 1993). It has been noted that, according to the partly floristic and partly physiognomic vegetation classification of White (1983), the vegetation of Africa bears a close relationship to the large-scale climate of the continent (Street-Perrott \& Perrott 1993). The similarity of precipitation and vegetation distributions is immediately apparent (Figs $1 \& 2$ ).

\section{PAST VEGETATION OF AFRICA}

There is a relatively much higher abundance of pollen data from the humid tropics and the continental extremities, as compared to the arid and semi-arid subtropics, such as the Sahel-Sahara zone and southern Africa. This is mainly due to the scarcity of rich pollen-bearing deposits such as lacustrine sediments and peats (Scott 1984) and the paucity of continuous pollen records where such deposits exist due to their hydrologically very sensitive settings, where there are periodic desiccations and cessation of sedimentation. There also exist some problems in interpreting pollen diagrams due to a lack of data on modern pollen production and dispersal mechanisms, for example on Mt. Kenya (van Zinderen Bakker \& Coetzee 1972). This problem has been partly resolved by the study of modern pollen dispersion at selected sites of interest (e.g. Hamilton 1972, Hamilton \& Perrott 1980, 1981). The identification of pollen types poses another problem, since many pollen types can only be identified to family or genus level, for example the grass pollen of Africa (Scott 1984). Furthermore, the role of environmental variables such as temperature and humidity in controlling the distribution of plant species is not well known-this has resulted in contentious interpretations of the palaeoecological significance of some species: for example, in eastern Africa, Artemisia pollen was assumed to be an indicator of cool, dry conditions (Coetzee 1967), while Street-Perrott \& Perrott (1993) maintain that its climatic significance is not well understood. In addition, lowland lake sediment records are beset by hiatuses as compared to highland lake and swamp sediment records, presumably mainly due to the relatively low precipitation: evaporation ratio in the lowlands.

Dating of the sediments has also been problematic, particularly in sequences in arid and semi-arid areas, by, for example, frequent hiatuses, lack of sufficient

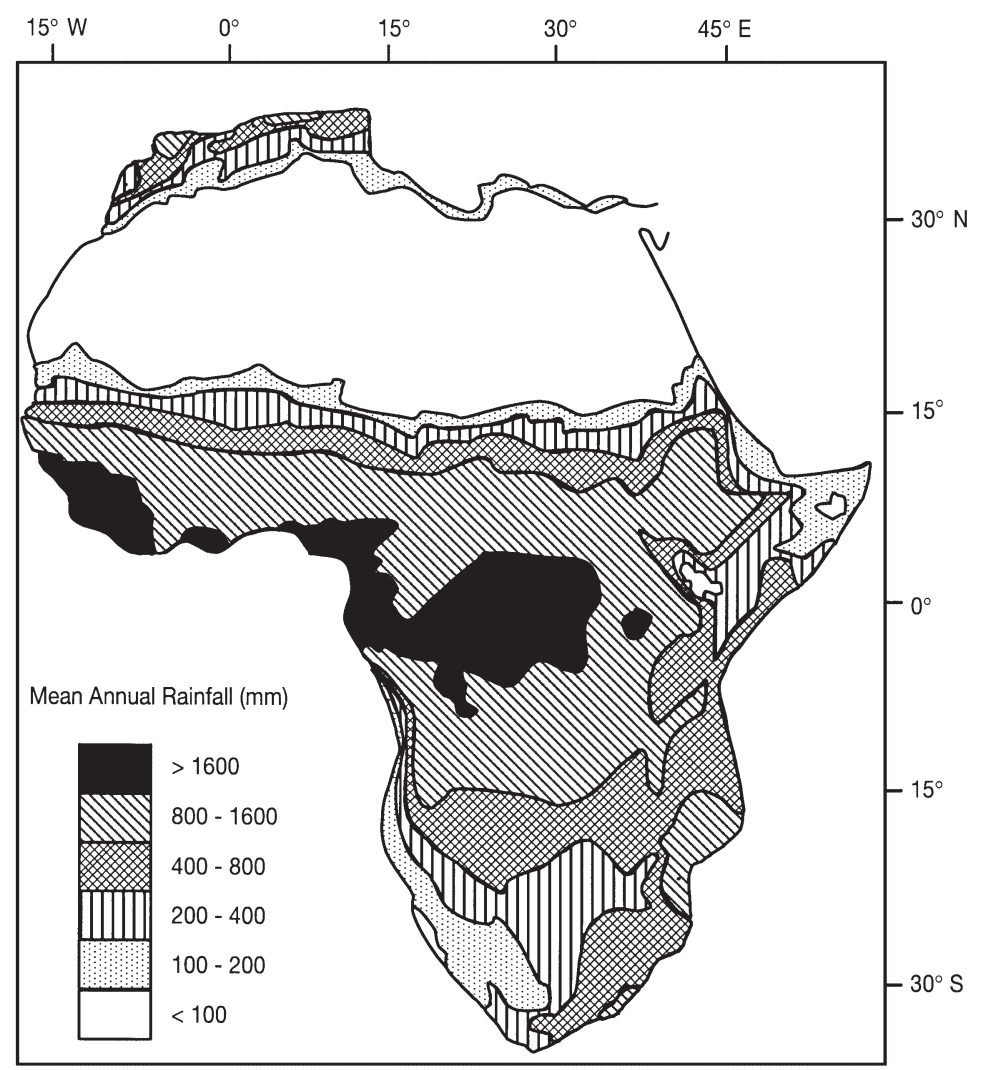

Fig. 1. Rainfall map of Africa (from Street-Perrott \& Perrott 1993; after Nicholson 1980) 


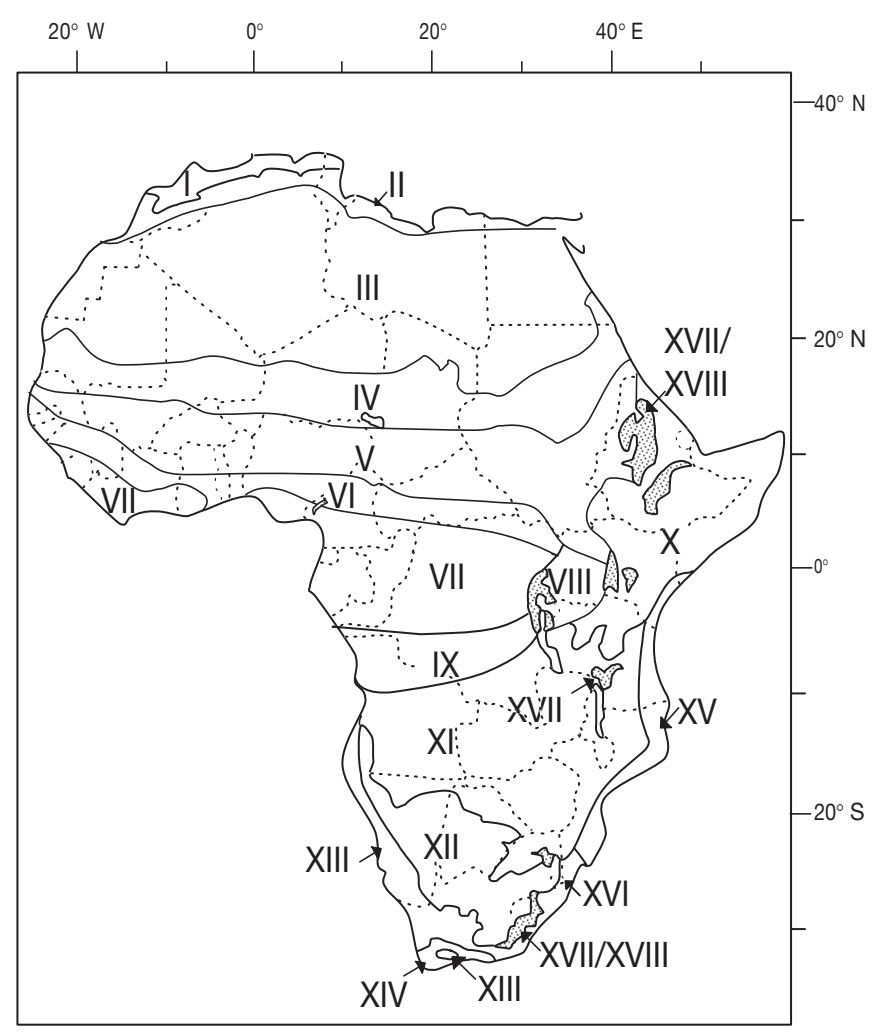

Fig. 2. Major floristic regions of Africa (from Street-Perrott \& Perrott 1993; after White 1983)

organic matter, contamination by juvenile $\mathrm{CO}_{2}$, contamination by younger organic matter. The records of vegetation change do not, generally, date beyond $40000 \mathrm{yr} \mathrm{BP}$, and in most cases they cover only the period 30000 yr BP to the present day. In the last few years, however, concerted efforts have been made to obtain longer, continuous, and radiometrically wellconstrained cores (e.g. Sacred Lake) to better understand the dynamics of tropical climate and environment over the last glacial-interglacial cycle.

\subsection{Northern Africa}

Floristic Zones I and II. Climate in the area of the Middle Atlas, Morocco, is strongly seasonal: total mean annual precipitation of $930 \mathrm{~mm}$ resulting from western cyclonic disturbances; falls mainly during the winter months of October to May.

\subsubsection{0 to 14000 yr BP}

The record of a $21 \mathrm{~m}$ core from Lake Tigalmamine $\left(32^{\circ} 54^{\prime} \mathrm{N}, 5^{\circ} 21^{\prime} \mathrm{W}\right.$; $1628 \mathrm{~m}$ a.s.l; mean annual precipitation $930 \mathrm{~mm}$ ), Middle Atlas, Morocco, indicates that between 18000 and 8000 yr BP the area was dominated by herb-rich grassland (Gramineae-Chenopodiaceae-Artemisia assemblage), suggesting that low moisture conditions prevailed at the time (Lamb et al. 1989). The dates in the littoral $21 \mathrm{~m}$ core are, however, tenuous because of depositional breaks prior to 4000 yr BP (Lamb \& van der Kaars 1995).

\subsubsection{0 to 10000 yr BP}

Between 14000 and 12000 yr BP, scattered evergreen oaks occurred in the region. Pollen analysis of marine cores from Gulf of Gabès and near Kneiss and Kerkennah islands, reflecting vegetation change in Tunisia, also indicates the spread of both deciduous and evergreen oaks and pine forests from $12000 \mathrm{yr}$ BP (Brun 1991). A second, continuous, well-dated, $16 \mathrm{~m}$ core from Tigalmamine, covering the Holocene, gives better information on vegetation change (Lamb \& van der Kaars 1995). Quercus forest had already surrounded the lake by $10500 \mathrm{yr}$ BP (basal age of the core); Artemisia and Gramineae counts at the base of the core are thought to record the transition from the arid late Pleistocene to humid Holocene environment (Lamb \& van der Kaars 1995).

\subsubsection{0 to 0 yr BP}

From 6200 yr BP, low levels of Cedrus pollen is found in the record, accompanied with a rise of Pinus pollen at a time when the diatom assemblage and ostracod $\mathrm{Mg} / \mathrm{Ca}$ profile suggests a change from shallow to deeper lake conditions, and decreased water salinity or decreased temperatures, respectively (Fig. 3) (Lamb \& van der Kaars 1995). Artemisia decreased at the same time in response to the increase in effective moisture (Lamb \& van der Kaars 1995). These results are consistent with those from Tunisia marine cores, which show an increase of shrub vegetation with Oleo-lentiscetum from $12000 \mathrm{yr}$ BP accompanied with an increase in hygrophilous plants until 4000 to 5000 yr BP (Brun 1991). Quercus canariensis and Cedrus increased at about $4600 \mathrm{yr} \mathrm{BP}$, indicative of moister conditions; the increase in $Q$. canariensis was interrupted by a brief but marked decline coinciding with the arid interval from ca 4500 to 4000 yr BP (Lamb \& van der Kaars 1995). From 4000 yr BP, Cedrus atlantica appears in the record (Lamb et al. 1989, Lamb \& van der Kaars 1995): it currently occupies cooler, moister parts of the Atlas Mountains than those where Quercus grows alone, implying a slight fall in temperature (Lamb et al. 


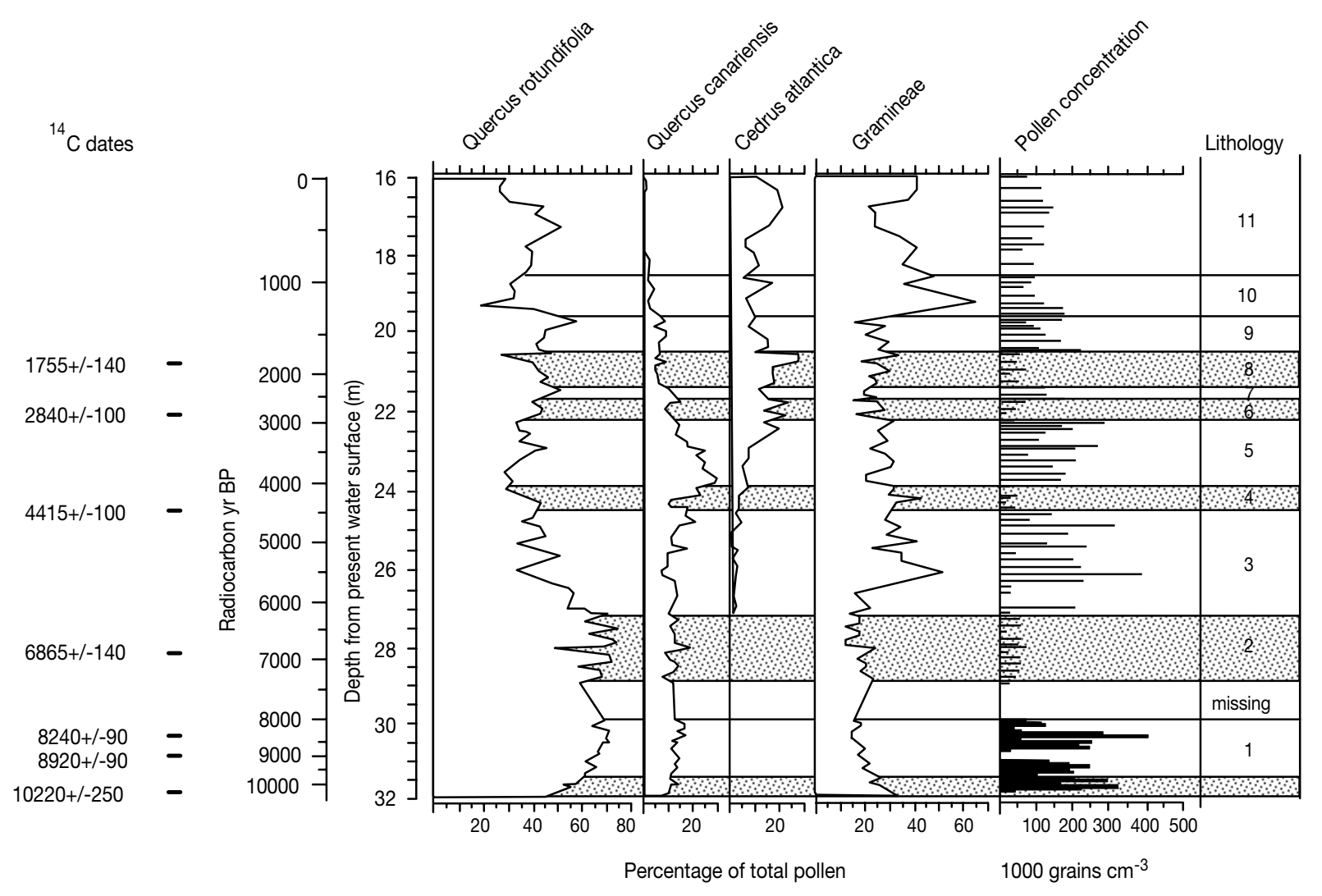

Fig. 3. Pollen stratigraphy of major taxa, Tigalmamine core C86. Shallow water phases inferred from palaeoecological data are indicated by shading (Lamb et al. 1994)

1989). Concordant with the appearance of $C$. atlantica, however, is an increase in $\delta^{18} \mathrm{O}$ on marl, which suggests a temperature increase: these observations are accounted for by change in the source and amount of precipitation, with western storm tracks bringing winter rain to the area (Lamb et al. 1989). The decline of Fraxinus and Q. canariensis at 2250 yr BP reflects the first anthropogenic influence in the area (Lamb et al. 1989, Lamb \& van der Kaars 1995).

The sequence of vegetation change in North Africa (Tigalmamine) from evergreen oak to deciduous oak and then cedar during the Holocene may be interpreted to be due to a progressive increase in available moisture (Lamb \& van der Kaars 1995). The contrast between the marked lacustrine response and the very muted vegetation response to short-term climatic events suggests that, during the arid intervals (lasting between 150 and 400 yr), precipitation may have remained sufficient to sustain plant growth in the summer growing season, whereas reduced precipitation in winter (normally the wettest season) resulted in depletion of the groundwater aquifer, leading to a lowered lake level without affecting vegetation because the mountain winters are too cold for plant growth (Lamb \& van der Kaars 1995, Lamb et al. 1995). The rapid response time of the lake level changes in Tigalmamine are thought to reflect higher frequency subMilankovitch climatic variations, while the vegetation responded to a lower frequency climate signal, probably modulated by orbital forcing (Lamb \& van der Kaars 1995). The regressions, representing short-term decreases in winter rainfall, may be related to sea surface conditions in the North Atlantic (Lamb et al. 1995).

\subsection{The Sahara-Sahel-Sudan Region}

Floristic Zones III, IV and V. The dominance of high pressure conditions is marked by below average precipitation. Mean annual precipitation is $<25 \mathrm{~mm}$ over most of the Sahara except for the high plateaux of Ahaggar and Tibesti, which receive $>100 \mathrm{~mm}$ mean annual precipitation. At present nearly all rains falling in the Sahel zone are monsoonal in origin. In summer (July-August) these rains reach the Ahaggar and Tibesti mountains. Over the central Sahara, available 
rains tend to fall during the spring (March to June) and Autumn (September to December), and are linked with tropical depressions. Southwesterly air may penetrate far north in summer in the southern Sahara and produce short-lived low pressure centres (Maley 1987, Barry \& Chorley 1992).

\subsubsection{0 to 14000 yr BP}

Maximum aeolian activity in the central Sahara occurred between 20000 and $18000 \mathrm{yr}$ BP, and subsequently appears to have spread southwards (van Zinderen Bakker 1980). The peak of aridity in the southern Sahara was reached after 18000 yr BP, probably correlated with the minimum evaporation of equatorial oceans, while the northern flank tended to become more humid as a result of the southward displacement of the Atlantic baroclinic zone and of the accompanying rain-producing eddies, supported by surface cooling and lower local evaporation (Flohn \& Nicholson 1980).

\subsubsection{0 to $10000 \mathrm{yr} \mathrm{BP}$}

The period 14000 to $10000 \mathrm{yr} \mathrm{BP}$ is characterised by abrupt warm/cold episodes with marked vegetation changes (Flohn \& Nicholson 1980).

\subsubsection{0 to 0 yr BP}

Two wet periods are documented to have occurred in the Sahara during the Holocene: at $9500 \mathrm{yr}$ BP and 6000 yr BP (Flohn \& Nicholson 1980). From 9000 to 5000 yr BP, a fauna with tropical and more humid affinities lived in the northern Sahara and was afterwards replaced by biota typical of drier open country: southern savannah vegetation invaded from the south, and Mediterranean vegetation invaded from the north (Flohn \& Nicholson 1980, Neumann 1991). Pollen analysis of lacustrine sediments from Senegal and Mauritania, from areas which are, at present, of Sahelian and Saharan nature, show rapid extension of humid vegetation towards the north from ca $9000 \mathrm{yr} B \mathrm{P}$ with maximum intensity at ca $8500 \mathrm{yr}$ BP, and are correlated with the intensification of the Atlantic monsoon (Lézine 1989). The maximum intensity is dated at 8500 yr BP and corresponds with a large body of evidence on lacustrine extensions in the Sahelian and Saharan subtropical latitudes (Lézine 1989). Tropical savannahs shifted 500 to $700 \mathrm{~km}$ northwards of their present range between 7000 and 6500 yr BP (this appears to have occurred simultaneously in the east- ern and central Sahara), receding slightly after $6000 \mathrm{yr}$ $\mathrm{BP}$ to $300-400 \mathrm{~km}$ north of their present range (Neumann 1991). From 5200 yr BP onwards, aridity increased and the savannah formations retreated to the south until the present status was reached by 3300 yr BP (Neumann 1991). The interval 4000 to 2000 yr BP was more humid in Senegal and Mauritania (Lézine 1989). In the Mauritania-Senegal region, forest destruction occurred at about $2000 \mathrm{yr}$ BP, when the present-day semi-arid environment was established (Lézine 1989).

In this region, climatic factors responsible for the increased humidity during the early to middle Holocene were: a weakening of the subtropical high pressure cells, an interplay of the influences of the Azores and the St. Helena anticyclones, a weakening of the upwelling off the west coast, and a higher evaporation from the ocean surface (Flohn \& Nicholson 1980). Due to the interplay of these factors, southern summer rains and northern winter rains alternated and overlapped considerably in area (Flohn \& Nicholson 1980).

\subsection{Western and Central Africa}

Floristic Zones VI, VII and IX. The West African Monsoon Trough generally oscillates between annual extreme locations of about $2^{\circ}$ and $25^{\circ} \mathrm{N}$ (Barry \& Chorley 1992). In accordance with the annual migration of quasi-permanent circulation systems, the regions nearest to the equator experience rainfall all year round, but the semi-arid desert fringe only at the height of the boreal summer, while double-peaked precipitation regimes with various timings are characteristic of the intervening latitudes (Hastenrath 1991).

\subsection{1. > 22000 yr BP}

Palynological investigations of temporally long records in marine sediment cores off the West African coast indicate that forest and woodland are more important during interglacial periods, while, during glacial periods, they are progressively replaced from north to south by grassland (e.g. Agwu \& Beug 1984). From 35000 yr BP through to the early Holocene, there were drastic reductions of forest, freshwater swamps and moist savannah communities in the Niger delta owing to adverse climatic conditions (Sowunmi 1981). During this period, forests in western and central Africa occurred in 3 isolated refugia; Upper Guinea, Cameroon-Gabon and eastern Zaïre, and are thought to have served as a buffer between Sudanian savannah to the north and Zambezian savannah to the south (Maley 1987). 
LAKE BAROMBI MBO, WESTCAMEROON

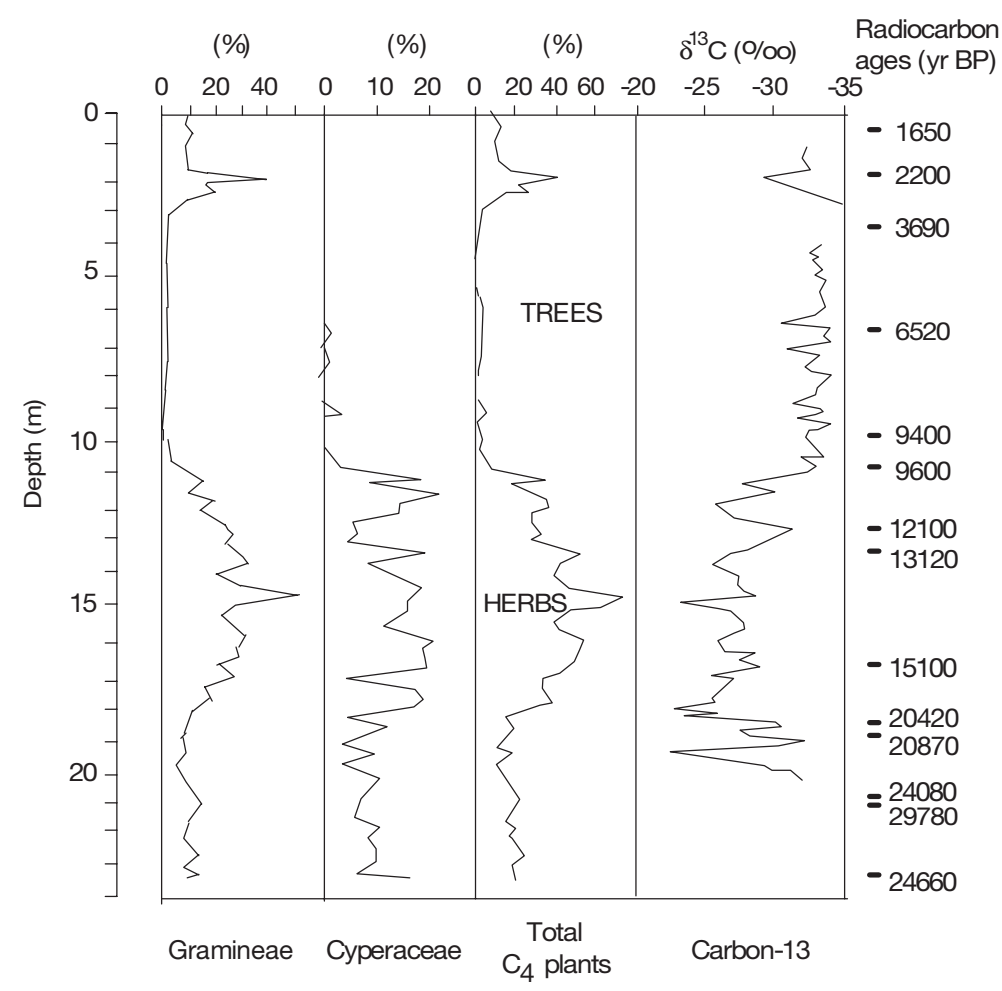

al. 1994) support pollen evidence of grassland $\left(\mathrm{C}_{4}\right.$ grasses) expansion during the last glacial maximum.

In response to both lowered temperatures and changes in humidity, montane biotopes of Ghana and West Cameroon (both forested and open) spread to low altitude, replacing the lowland forests, which occurred in 3 isolated refugia: Upper Guinea, Cameroon-Gabon, and eastern Zaïre (Maley 1987). The changes in temperature between the last glacial maximum and present (lowered by 5 to $8^{\circ} \mathrm{C}$ relative to present), in western Africa, are attributed to the interaction between tropical Atlantic upwelling and cloud formation: stratiform cloud cover produced by the cold Atlantic waters (maximum lowering during the last glacial maximum of 8 to $9^{\circ} \mathrm{C}$ ) caused a cooling and drying of the adjacent land areas (Maley 1987). These clouds formed persistent cover which produced little or no rain, but intercepted solar radiation, causing lower temperatures (Maley 1987).

\subsubsection{0 to $10000 \mathrm{yr} \mathrm{BP}$}

The $\delta^{13} \mathrm{C}$ curve of a $23.5 \mathrm{~m}$ core from Lake Barombi Mbo, Cameroon (Fig. 4) ( $4^{\circ} 40^{\prime} \mathrm{N}, 9^{\circ} 24^{\prime} \mathrm{E}$; $300 \mathrm{~m}$ a.s.l.), exhibits an almost linear correlation with the curve of the total grass pollen, which forms the main part of the $\mathrm{C}_{4}$ biomass; it has isotopically relatively light values, indicating a forest environment with some montane flora from 25000 to 20000 yr BP (Giresse et al. 1994).

\subsubsection{0 to 14000 yr BP}

A mosaic of forest and savannah around Lake Barombi Mbo, accompanied by a fall in the lake level and colonisation of the shores by Cyperaceae and other aquatic plant species, is inferred from pollen and carbon isotope data for the period 20000 to $13000 \mathrm{yr}$ BP (Fig. 4) (Giresse et al. 1994). In Lake Bosumtwi, Ghana, a dry, semi-deciduous type of forest, similar to the present-day type, existed at the PleistoceneHolocene boundary (Talbot \& Hall 1981). Pooid grasses (identified by grass cuticle analysis), and Olea hochstetteri pollen at the Pleistocene-early Holocene boundary imply palaeotemperatures several degrees lower than today in southern Ghana (Talbot et al. 1984). The $\delta^{13} \mathrm{C}$ values in Lake Bosumtwi (Talbot \& Johannessen 1992) and Lake Barombi Mbo (Giresse et
From 13000 to $10000 \mathrm{yr}$ BP, there was forest extension in the Lake Barombi Mbo area (Giresse et al. 1994). Two short dry phases, marked by positive $\delta^{13} \mathrm{C}$ spikes, are dated by interpolation at 11200 and 10300 yr BP (Giresse et al. 1994). In the region of Congo, the forest underwent major expansion from ca 12000 yr BP (Giresse \& Lanfranchi 1984).

\subsubsection{0 to 0 yr BP}

A dramatic rise in the abundance of arboreal pollen in Lake Barombi Mbo suggests that forest rapidly replaced grassland after 9000 yr BP (Talbot et al. 1984); maximum forest density, with average $\delta^{13} \mathrm{C}$ values of $-32 \%$, occurred between 9500 and 3000 yr BP (Giresse et al. 1994). Continuous forest became established between 7500 and 5000 yr BP in Lake Bosumtwi (Talbot \& Hall 1981); the early stages are concomitant with the more humid conditions recorded in the Niger Delta between ca 7600 and $6960 \mathrm{yr}$ BP, when freshwater swamp and rainforest components increase in the pollen assemblages (Sowunmi 1981). Palynological and sedimentological records from Lake Barombi Mbo show climatic deterioration between 4000 and $3000 \mathrm{yr}$ BP and between 2500 and 2000 yr BP (Maley 1992), 
with temporary forest openings reflected during the latter period by $\delta^{13} \mathrm{C}$ excursion above $-30 \%$ (Giresse et al. 1994). Reduction in rain forest communities after 3000 yr BP in the Niger Delta is attributed to human disturbance through agricultural practices (Sowunmi 1981).

\subsection{Eastern Africa}

Floristic Zones VIII and X. During December to February, the northeast monsoon sweeps down the western Indian Ocean and adjacent East Africa, extending to well south of the equator. During July and August, the southeast trades of the southern hemisphere recurve near the equator and form the origin of the northern hemisphere southwest monsoon. Most rain occurs during the passage of the Intertropical Convergence Zone (ITCZ). Deep westerlies originating from the Atlantic Ocean and the moist Zaïre Basin between June and August are associated with widespread cloudy and rainy weather in western parts of East Africa (Jackson 1961, Thompson 1965, Hastenrath \& Lamb 1979, Hastenrath 1984, Ogallo 1989).

\subsection{1. > 22000 yr BP}

Perhaps the longest continuous records so far retrieved from East Africa are those from Sacred Lake, Mount Kenya (Coetzee 1967, Olago 1995, Street-Perrott et al. 1997, Olago et al. 1999), and Rukiga Highlands (Taylor 1990), spanning the period from $115000 \mathrm{yr}$ BP and $>42000 \mathrm{yr}$ BP to present, respectively. Prior to 42000 yr BP, the Sacred Lake site was characterised by unstable vegetation consisting of Ericaceous belt taxa with elements of humid forest (Fig. 5) (Coetzee 1967, Olago 1995), while in the Rukiga Highlands around Muchoya Swamp (11' $\mathrm{S}, 2^{\circ} 48^{\prime} \mathrm{E}$; $2260 \mathrm{~m}$ a.s.1.), moist lower montane forest vegetation (indicated by, e.g., Croton comp., Ilex, Neoboutonia, Minulopsis comp., Urticaceae, Myrtaceae, Macaranga, Nuxia and Filcahoa) existed, prior to 42000 yr BP, suggesting that conditions were similar then to those existing today (Taylor 1990).

Between 42000 and $22000 \mathrm{yr} \mathrm{BP}, \delta^{13} \mathrm{C}$ values in Sacred Lake indicate a co-dominant $\mathrm{C}_{3}-\mathrm{C}_{4}$ ecosystem, reflecting open forest vegetation at the lake (Coetzee 1967, Olago 1995, Olago et al. 1999). A Hagenia dominated treeline existed at the altitude of the lake with Ericaceous belt elements (van Zinderen Bakker \& Coetzee 1972, Street-Perrott \& Perrott 1993, Olago 1995). The period between 42000 and 34000 yr BP on Mount Kenya (Olago 1995) was relatively dry, following which humid conditions occurred. Other evidence of dry con- ditions in East Africa before 30000 yr BP come from Lake Abiyata $\left(7^{\circ} 10^{\prime} \mathrm{N}, 37^{\circ} \mathrm{E} ; 1600 \mathrm{~m}\right.$ a.s.l.), Ethiopia, which indicates a generally semi-arid environment almost similar to present-day conditions with slight temperature changes (Lézine 1982), and Karimu Mire basin $\left(0^{\circ} 30^{\prime} \mathrm{S}, 36^{\circ} 41^{\prime} \mathrm{E} ; 3040 \mathrm{~m}\right.$ a.s.l.), Aberdare range, Kenya, where clay deposition and the absence of organic matter before 32000 yr BP imply that vegetation was absent or sparse in the surrounding area, while analysis of pollen indicates that shortly thereafter, dry conditions depressed vegetation belts: Hagenia (indicating forest-edge conditions) and Olea (Olive) dominated, while Juniperus (Cedar), Podocarpus (YellowWood) and Urticaceae were virtually absent (Perrott \& Street-Perrott 1982). Until 32000 yr BP in the Rukiga Highlands, Ericaceous belt species such as Anthospermum, Cliffortia, Artemisia and Stoebe are found, indicating a substantial altitudinal depression of vegetation belts, and a cold, dry period relative to the present (Taylor 1990). At the Burundi site (Kashiru Swamp, $3^{\circ} 28^{\prime} \mathrm{S}, 29^{\circ} 34^{\prime} \mathrm{E} ; 2104 \mathrm{~m}$ a.s.l.), temperatures were estimated at about $4^{\circ} \mathrm{C}$ colder than now prior to $30000 \mathrm{yr}$ BP (Bonnefille et al. 1990), in association with the occurrence of montane evergreen (gymnosperm) forest (Cliffortia, with Podocarpus, Macaranga, and Olea common) above $2200 \mathrm{~m}$, and the development of Ericaceae around the swamp (Bonnefille \& Riollet 1988, Bonnefille et al. 1990). It was also wetter than present (Bonnefille \& Riollet 1988, Bonnefille et al. 1990). $\delta^{13} \mathrm{C}$ data for the period 30000 to $22000 \mathrm{yr}$ BP in the Rukiga and Burundi Highlands indicate that $\mathrm{C}_{4}$ plants were dominant (Aucour \& Hillaire-Marcel 1993, Aucour et al. 1994) and are supported by the pollen diagram for Kashiru Swamp (Fig. 5) which shows a sharp decline in forest taxa at $29000 \mathrm{yr}$ BP and an increase in Gramineae (Bonnefille \& Riollet 1988). A warm phase occurred ca 26000 yr BP as evidenced by fossil pollen from the Cherangani Hills in Kenya $\left(1^{\circ} \mathrm{N}, 35^{\circ} 28^{\prime} \mathrm{E}\right.$; $3292 \mathrm{~m}$ a.s.1.), with temperatures between 2 and $4.1^{\circ} \mathrm{C}$ lower than at present (Coetzee 1967).

\subsubsection{0 to 14000 yr BP}

A wet episode, characterised by increases in Compositae, Alchemilla and Hypericum (St. Johns wort) pollen, and a decrease in Gramineae and Cyperaceae pollen, is recorded at $21500 \pm 1250 \mathrm{yr}$ BP at Kashiru (Bonnefille \& Riollet 1988). In Muchoya Swamp, the pollen spectra of 5 cores (ranging between 8 and $10 \mathrm{~m}$ ) indicate that Hagenia forest dominated between 25000 and $17000 \mathrm{yr}$ BP (the dates are based on an extrapolation of 3 radiocarbon dates along the profile of the longest core) (Morrison 1968). In Muchoya Swamp, the Hagenia forest was replaced by Erica- 


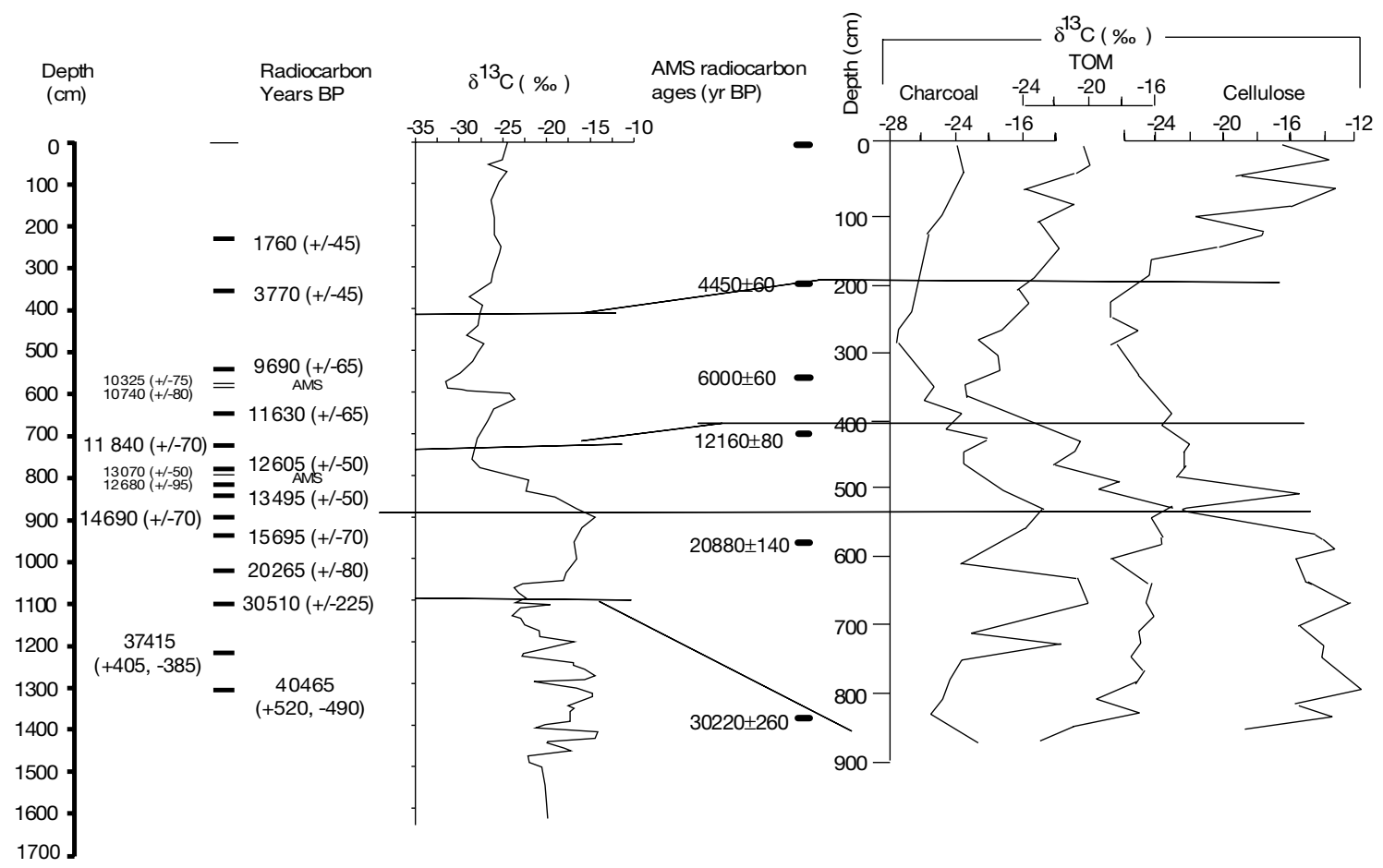

KASHIRU POШEN DIAGRAM, BURUNDI

AMS radiocarbon Depth

ages $(\mathrm{yr} \mathrm{BP}) \quad(\mathrm{cm})$
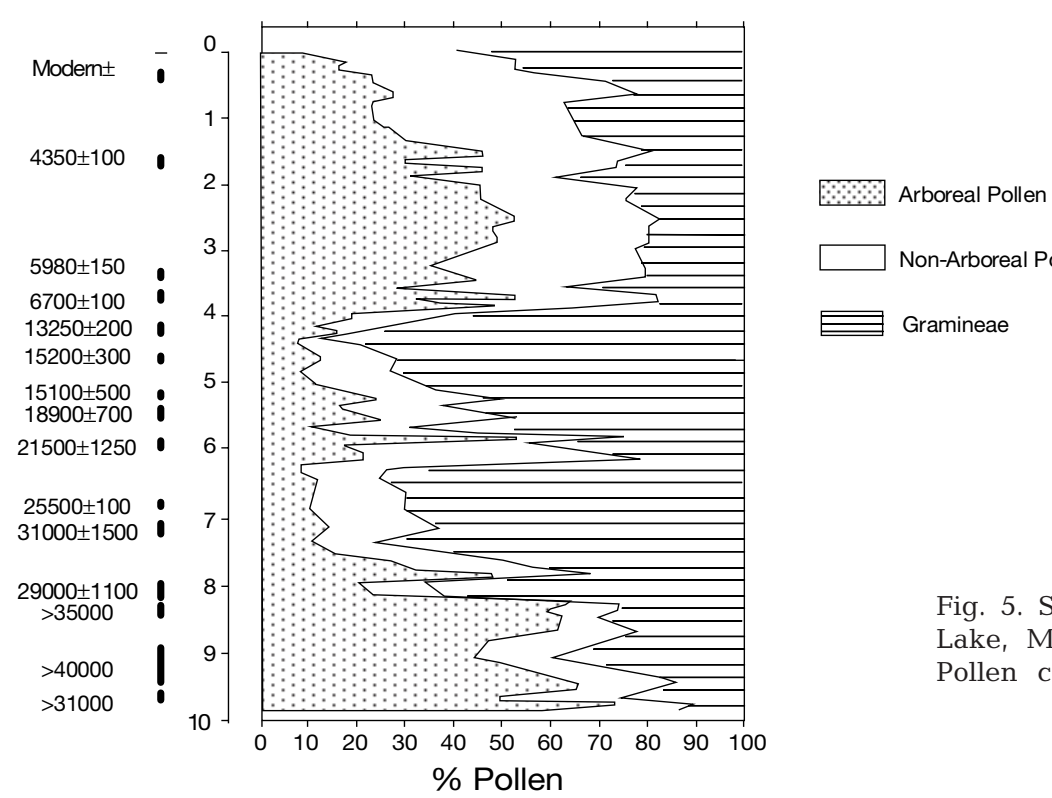

Non-Arboreal Pollen

Gramineae

Fig. 5. Stable carbon isotope trends in Sacred Lake, Mount Kenya, and Burundi Highlands. Pollen counts for Kashiru, Burundi, are also shown

ceous belt vegetation (Morrison 1968, Taylor 1990), with Stoebe kilimandscharica and much grass pollen persisting through to $11000 \mathrm{yr} \mathrm{BP}$, suggesting a mean annual temperature between 5 and $8^{\circ} \mathrm{C}$ lower than today (Morrison 1968). Dry montane scrub (Anthosper- mum, Ericaceae and Hagenia) persisted around Ahakagyezi Swamp in the Rukiga Highlands between 21000 and 14000 yr BP (Taylor 1990). In the Burundi Highlands, an altitudinal depression of between 1000 and $1500 \mathrm{~m}$ compared to the present occurred (Bon- 
nefille et al. 1990). The extension of montane grasslands (characterised by high percentages of Gramineae and Compositae) in the pollen record is observed between 22000 and 15000 yr BP in Kashiru (Roche \& Bikwemu 1989). The persistence of the tree taxa Podocarpus and Olea, and the occurrence of Myrica, Ilex, Syzygium, and Canthium during the glacial period, point to the existence of local refuges in the neighbourhood of the Kashiru site (Bonnefille \& Riollet 1988). Temperatures in Burundi were correspondingly cool (Bonnefille et al. 1990).

On Mt. Elgon, the extent of the forest and macrophyllous thicket was much less than at present between $>23000$ and $<14000 \mathrm{yr} \mathrm{BP}$, and there is evidence of a depression of vegetation belts (Hamilton 1987). At the Cherangani site, Afroalpine vegetation became established (Coetzee 1967). Dry cool conditions persisted in Karimu Mire until ca 11000 yr BP (Perrott \& Street-Perrott 1982). In Lake Naivasha $\left(0^{\circ} 45^{\prime} \mathrm{S}, 36^{\circ} 20^{\prime} \mathrm{E}_{;} 1890 \mathrm{~m}\right.$ a.s.l. $)$, the arid glacial (immediately prior to $20290 \mathrm{yr}$ BP to about $12270 \mathrm{yr}$ BP) was characterised by Chenopodiaceae, Amaranthaceae, Compositae, and Anthospermum (indicators of dry conditions), with low Olea and Podocarpus pollen (Maitima 1991). Gramineae, Chenoams, Compositae and Sesbania dominate prior to $18000 \mathrm{yr}$ BP (Maitima 1991). A short episode of moderately wet climate and moderate forest expansion on the Aberdare mountains is inferred between ca 17000 and $15000 \mathrm{yr}$ BP and is characterised by slightly higher percentages of the forest taxa Podocarpus, Olea, Celtis, Anthospermum and Hagenia; these pollen types, with the exception of Podocarpus, decline sharply towards the end of this episode (Maitima 1991). Street-Perrott \& Perrott (1993) note that, during the early part of this period in Sacred Lake, there were rapid shifts in major pollen types, changing from Hagenia to Podocarpus to Cliffortia, and suggest that this could signal the beginning of cold climate with initially dry conditions. Distinguishing features at Sacred Lake during this period are: a gradual decline of Cliffortia and Stoebe pollen percentages and a concomitant rise in Ericaceae and Artemisia pollen, possibly indicating a lowering of higher altitude vegetation, drier climate and a continued decrease in temperature at the altitude of the lake (Coetzee 1967, van Zinderen-Bakker \& Coetzee 1972). The $\delta^{13} \mathrm{C}$ values indicate a change in catchment vegetation from open forest to $\mathrm{C}_{4}$-dominated grasslands up to about $13500 \mathrm{yr} \mathrm{BP}$, when there was a resurgence of $\mathrm{C}_{3}$ species at a time of lake desiccation (Fig. 5) (Olago 1995, Olago et al. 1999). The initial abrupt shift in the $\delta^{13} \mathrm{C}$ values (from lighter to heavier values) at $22000 \mathrm{yr}$ $\mathrm{BP}$ is consistent with the observation of the rapid shift in pollen types (Olago 1995, Olago et al. 1999). A cool dry climate with Cliffortia and a decrease in Hagenia (reflecting treeline depression) persisted to $14050 \mathrm{yr}$ BP (Street-Perrott \& Perrott 1993). The trends in Sacred Lake are similar to those observed in Lake Rutundu, Mount Kenya: alpine zone vegetation consisting mainly of grassland mixed with Artemisia, other Compositae and scattered Ericaceae represent a cold, dry climate between ca 18000 and ca 10800 yr BP, with very dry climate being characteristic of the period up to ca 11600 yr BP (Coetzee 1967).

Bonnefille et al. (1990) used multivariate statistical analysis (based on an extensive modern data set [356 sites] from East and Central Africa between latitudes $4^{\circ} \mathrm{S}$ and $12^{\circ} \mathrm{N}$ and longitudes $28^{\circ}$ to $42^{\circ} \mathrm{E}$, covering desert, subalpine grassland and all forest types) on a 40000 yr (radiocarbon dated) pollen profile from Kashiru Swamp to derive quantitative estimates of past temperatures in tropical Africa. They derived, for the last glacial period, a temperature decrease of $4 \pm 2^{\circ} \mathrm{C}$, which is slightly lower than previously inferred values, and a simultaneous 30\% decrease in mean annual rainfall, which is in broad agreement with the concomitant lake level declines in the East African region. Using a similar method, Vincens et al. (1993) gave an estimated temperature drop of $4.2 \pm 3.6^{\circ} \mathrm{C}$ and a mean precipitation drop of $15 \%$ (with a large deviation) for Lake Tanganyika. Livingstone (1971) noted that the pollen assemblages covering this period generally reflect lower precipitation or a more uneven seasonal distribution in rainfall; thus the large deviations from the mean precipitation values calculated by Bonnefille et al. (1990) and Vincens et al. (1993) might reflect uneven seasonal distribution of rainfall.

\subsubsection{0 to $10000 \mathrm{yr} \mathrm{BP}$}

Some of the pollen curves of the Cherangani Hills indicate that the cold climate was coming to an end at about 12400 yr BP (Coetzee 1967). Kendall (1969) observed from a palynological study of a core taken from Pilkington Bay, Lake Victoria, that prior to 12000 yr BP, forest was either absent or of small extent in the area. The terminal phase of the last glaciation at Lake Bogoria (14680 to $12050 \mathrm{yr}$ BP) was characterised by an abundance of herbaceous taxa, e.g. Gramineae, Cyperaceae, Compositae, and Typha, and to a much lesser extent, the tree pollen Podocarpus, Juniperus, Myrica, Olea, Phoenix (wild date palm) Celtis, Allophylus and Macaranga, amongst others; tree pollen became progressively much more abundant and diversified, with Prunus africana, Stoebe kilimandscharica, Hagenia abyssinica and Schrebera alata being found exclusively within this zone (Vincens 1986). In Sacred Lake, sedimentological evidence indicates that the period of maximum aridity occurred just before 
$13500 \mathrm{yr} \mathrm{BP}$, at a time when there was a change from $\mathrm{C}_{4}$-dominated to a $\mathrm{C}_{3}$-dominated vegetation community (Olago 1995, Olago et al. 1999); this is supported by the occurrence, after 14050 yr BP, in Sacred Lake of maximum Artemisia pollen values, which indicate an accentuation of dry conditions, and increases in Cliffortia and, later, Hagenia pollen could indicate a slight climatic amelioration (Coetzee 1967). Small Celtis pollen maxima (currently found on the plateau and lower altitudes in the forests of Mt. Kenya) may indicate moister conditions in the lowlands at ca $12300 \mathrm{yr}$ BP. Street-Perrott \& Perrott (1993) noted that the Sacred Lake pollen assemblages between 14000 and 10000 yr BP are presently climatically indistinguishable, although they observe slightly higher values of Artemisia and moister montane forest tree species, e.g. Hagenia, and a decline in Podocarpus. Increases in humidity after 11600 yr BP at Lake Rutundu are indicated by low counts of Artemisia pollen and increasing Hagenia pollen (Coetzee 1967). Highest values of Ericaceae between 10800 and 10300 yr BP at Lake Rutundu coincide with reduced Gramineae and montane forest zone elements (Hagenia, Podocarpus, etc.) in Sacred Lake, and a definite increase in temperature is recorded at ca 10300 yr BP by the dominant Ericaceous zone pollen (Coetzee 1967). A temperature increase is inferred in the Burundi Highlands between 15000 and 13000 yr BP (Roche \& Bikwemu 1989, Bonnefille et al. 1990). This period also coincides with the maximum extension of grassland in the region, and with the lowest tree diversity and the noticeable occurrence of Artemisia (Bonnefille \& Riollet 1988). Stable carbon isotope data show expansion of $\mathrm{C}_{4}$ grasslands in this area (Aucour \& Hillaire-Marcel 1993, Aucour et al. 1994). A slight climatic amelioration, marked by some expansion of montane forest at ca $14000 \mathrm{yr} \mathrm{BP}$, is also observed around Muchoya and Ahakagyezi Swamps in the Rukiga Highlands (Taylor 1990). In the region of Congo, the forest underwent major expansion from ca 12000 yr BP (Giresse \& Lanfranchi 1984).

The period 12400 to 10000 yr BP marked a time of climatic transition, with rising temperatures and an increasingly moist climate; details remain unclear, and there were probably large climatic fluctuations such as a brief return to arid conditions just prior to $10000 \mathrm{yr}$ BP (Coetzee 1967, Flenley 1979a,b, Hamilton 1982). Progressive humidity is observed during the terminal Pleistocene in Lake Abiyata (Lézine 1982). In the Mt. Elgon area the forest began to spread and diversify due to a moistening climate, culminating in the establishment of mesic montane forest by $9000 \mathrm{yr}$ BP (Hamilton 1987). At ca 12000 yr BP forest appeared in the Pilkington Bay (Lake Victoria) area, and declined shortly at ca 10000 yr BP (Kendall 1969). Around Lake Bogoria, there was a decline in Gramineae and Cyper- aceae, while Pteridophytes and arboreal pollen increased; the latter included the Combretaceae, Phoenix, Podocarpus, Olea and Macaranga, while Juniperus and Myrica became rare (Vincens 1986). At this time, the Lake Naivasha region was characterised by an Olea-Podocarpus assemblage, with Myrica, Rapanea, Celtis, Pygeum, and Artemisia (Maitima 1991), indicating a succession of forest vegetation, and suggesting a wet climate (Maitima 1988). Although the continued occurrence of Anthospermum, Artemisia and Stoebe pollen between 13800 and 11000 yr BP indicates that the Ericaceous belt vegetation was still present around Muchoya, the abundance of Hagenia and Urticaceae pollen from ca $12000 \mathrm{yr} \mathrm{BP}$, and the contemporaneous establishment of Hagenia-dominated woodland around Ahakagyezi, indicates an expansion of moist forest types and an altitudinal elevation of vegetation belts resulting from temperature and precipitation increases (Taylor 1990). Further increases in temperature are indicated in the Muchoya and Ahakagyezi pollen spectra at ca 11100 and $10600 \mathrm{yr}$ BP, when moist lower montane forests became established at the sites (Taylor 1990). At Muchoya Swamp in southwest Uganda, Hagenia forest was re-established at ca $11000 \mathrm{yr}$ BP (Morrison 1968). The $\delta^{13} \mathrm{C}$ data show an increase in $\mathrm{C}_{3}$ plants (Aucour \& Hillaire-Marcel. 1993, Aucour et al. 1994). Open forest began to be established at $12000 \mathrm{yr}$ BP around the north basin of Lake Tanganyika, achieving its maximum development and diversity at about 10000 yr BP, while the forests and the Afroalpine belt vegetation regressed considerably, attaining, by $10000 \mathrm{yr} \mathrm{BP}$, a position close to that observed today (Vincens 1989a). Around the south basin of Lake Tanganyika, montane forest communities abruptly retreated at $12000 \mathrm{yr}$ BP, whereas the Zambezi woodlands greatly expanded and diversified (Vincens 1989b). These changes occur within the context of a climatic amelioration, primarily related to temperature increases (Vincens 1989a,b).

\subsubsection{0 to $0 \mathrm{yr} \mathrm{BP}$}

From 10000 to 4000 yr BP, climatic changes are evidenced by major alterations in plant communities. In Sacred Lake, forest pollen types become exceedingly dominant from 10560 to ca $6000 \mathrm{yr}$ BP, and marked declines in Ericaceous zone pollen occur (Coetzee 1967, van Zinderen Bakker \& Coetzee 1972). A pollen spectrum from the Galana Boi Beds of the northeast Lake Turkana basin is characterised by montane forest and thicket taxa not found in modern pollen; these pollen are thought to have been transported to the lake by rivers originating in the Ethiopian Highlands, suggesting both increased runoff and an extension of the 
highland forests (Owen et al. 1982). This, coupled with the high percentage of Pteridophytes, suggests increased rainfall over the catchment (Owen et al. 1982). The local elements are dominated by herbaceous pollen, notably Gramineae and Compositae, and arboreal forms are uncommon (Owen et al. 1982). However, the occurrence of more humid vegetation types near the lake (compared to present vegetation) suggest an increase in rainfall, measuring at least $200 \mathrm{~mm}$ $\mathrm{yr}^{-1}$ above the modern average (Vincens 1989c). During the early Holocene at Cherangani, the lowest part of the Ericaceous belt, with Stoebe dominant, became established. The Lake Naivasha pollen sequence shows that the vegetation established at ca $12070 \mathrm{yr}$ BP persisted until ca 6500 yr BP (Maitima 1991). At ca 6500 yr BP tree taxa such as Rapanea and Pygeum disappeared from the Lake Naivasha pollen record, while Podocarpus and Olea became more abundant, and Alchemilla appeared in the record, with higher percentages of Chenoams and Amaranthus, indicating that dry conditions were initiated at this time (Maitima 1991). At Pilkington Bay, the forest returned after a short decline at ca $10000 \mathrm{yr} \mathrm{BP}$, and there was a shift from evergreen to semi-deciduous forest between 7000 and 6000 yr BP (Kendall 1969). From 6000 to 5000 yr BP, there is a pronounced resurgence of the Hagenia pollen curve in Sacred Lake (van Zinderen Bakker \& Coetzee 1972); the increase in Hagenia pollen values and the decrease in Gramineae suggest that forest was moving up the mountain as conditions became warmer and wetter (Street-Perrott \& Perrott 1993).

In Kashiru, an important extension of montane forest occurred between ca 10000 and ca 5000 yr BP (Roche \& Bikwemu 1989). Morrison (1968) recorded a shift from moist montane Hagenia forest to a mixed montane or bamboo forest in Muchoya Swamp at ca 6000 yr BP, marked by a sharp decline in Hagenia and a sharp increase in Ericaceae, and explained this change as being possibly due to human influence, as interpreted in the nearby Butongo Swamp (M. E. S. Morrison unpubl. data), where Polyscias (and Olea) succeeds Hagenia abruptly, and Polyscias fulva (a well-known tree of secondary succession with a short life span of $40 \mathrm{yr}$ or less) persists through $9 \mathrm{~m}$ of lake sediment. However, the Butongo sequence was not radiocarbon dated. Around the north basin of Lake Tanganyika, an increase in rainfall is inferred at $10000 \mathrm{yr}$ BP from the pollen spectrum and is supported by a great increase in fern pollen, transported also by rivers and streams (Vincens 1989a). This wet and warm phase characterised a major part of the Holocene around the northern basin of Lake Tanganyika (Vincens 1989a).

By the middle Holocene, climatic conditions in the Turkana region had become more comparable with those at present, based on the pollen assemblages, which are dominated by Gramineae, with rare arboreal taxa (Owen et al. 1982). From the Lake Baringo site, increases in Podocarpus, Juniperus and Olea and the development of Acacia and Dodonea are observed at ca 4500 yr BP and from 2500 yr BP to the present, while those characteristic of high altitude forest, such as Hagenia abyssinica, Hypericum, Stoebe, and Ericaceae no longer occur (Vincens 1986). There are no indications of lowland forest in the Lake Naivasha region after ca $4000 \mathrm{yr}$ BP (high values of the relatively high-export pollen types Podocarpus and Olea are recorded in the pollen sequence and are thought to be far travelled), and the climate was hot and dry (Maitima 1991). Perrott (1982a,b) observed that a sharp increase in Podocarpus pollen (which signifies the onset of drier conditions), dated at ca $3720 \mathrm{yr}$ BP at Kimilili Lake (Mt. Elgon), correlates to that observed from the Hobley Valley mire of Mount Kenya (4265 m a.s.l.). From 5000 to 3285 yr BP, pollen of montane forest species become dominant at Sacred Lake, and Hagenia pollen is almost absent; warm, wet conditions, marked by pollen of wetter montane forest, e.g. Afrocrania, Prunus and Neoboutonia (Street-Perrott \& Perrott 1993), reached a maximum at about $4000 \mathrm{yr}$ BP (van Zinderen Bakker \& Coetzee 1972). The sharp rise in Podocarpus pollen shortly after 4000 yr BP (StreetPerrott \& Perrott 1993) correlates with a similar rise in the Hohnel Valley mire, marking the onset of drier conditions (Perrott 1982b). From 3285 yr BP to present, very high values of Podocarpus and other montane forest elements (e.g. Olea, Macaranga, Pygeum, Neoboutonia, Galiniera and Celtis) indicate the development of the Dry Montane Rain Forest (Coetzee 1967, StreetPerrott \& Perrott 1993). From ca 4620 yr BP much higher humidities are recorded on Mount Kilimanjaro, during which time the forest at the Cherangani site reached its maximum (Coetzee 1967). This has been explained by a temperature rise which caused the clouds to be formed at a higher altitude than at present (Coetzee 1967). Hamilton et al. (1986) note increases in Podocarpus, Olea and Syzygium pollen at Ahakagyezi Swamp between 3500 and 3600 yr BP. However, Taylor (1990) observed that expansions of dry forest taxa around Ahakagyezi and Muchoya occurred after ca 3900 and 3400 yr BP respectively. In Kashiru Swamp, a significant extension of Gramineae and Ericaceae, accompanied by a decline of all forest elements except Podocarpus, Maytenus and Hypericum, occurred (Roche \& Bikwemu 1989). Roche \& Bikwemu (1989) noted a cold and dry period centred around 2500 yr BP in the Kashiru area. In the region of Congo, a slight trend towards aridity is evident from $3000 \mathrm{yr}$ BP south of the equator (Giresse \& Lanfranchi 1984). From 2500 yr BP a progressive degradation of the 
arboreal cover and a concomitant development of Gramineae is observed in the north basin of Lake Tanganyika and is related to an increasingly dry climate and possibly to human interference (Vincens 1989a). However, traces of cultures or plantations are seen only in the surface sediments of the cores, where rare pollen such as Elaeis guineensis (wild oil palm) occurs (Vincens 1989a).

\subsection{Southern Africa}

Floristic Zones XI, XII, XIII, XIV. Climate south of $15^{\circ} \mathrm{S}$ is subtropical and semi-arid. Summer rainfall is greatest in the north and east in association with subtropical convection in close proximity to warm sea surface temperatures. The southwest Cape region experiences a Mediterranean-type climate with winter rain during May to July and summer drought from November to January due to influence of westerly air streams.

\subsection{1. > 22000 yr BP}

In general, scarcity of radiocarbon dates and uncertain age determinations only allow questionable inferences to be made on vegetation history of the period before 25000 yr BP (Scott 1990). No single detailed palaeovegetation record exists for the whole Quaternary, but shorter pollen profiles show marked shifts in modern phytochoria in response to glacial-interglacial changes in climate (Scott et al. 1997). More specifically, the vegetation changes in southern Africa comprised wide shifts in biome composition and boundaries, attributed to orbitally related fluctuations in temperature, precipitation and seasonal distribution patterns of moisture (Scott et al. 1997). The $190000 \mathrm{yr}$ pollen sequence from the Tswaing Crater (the Pretoria Saltpan), although discontinuous in places (15000 to 21000,25000 to 31000 and 80000 to $150000 \mathrm{yr}$ $\mathrm{BP})$, is the longest Quaternary sequence from South Africa (Scott 1999). The record shows marked cycles of vegetation change in South Africa's savannah biome, with pollen types ranging between Podocarpus forest pollen, warm woodland savannah elements, dry savannah elements and cool or temperate shrubland (fynbos) elements (Scott 1999). The pollen data from the Tswaing Crater have been compared with that of the nearby Wonderkrater sequence (Scott 1999) and the following climatic inferences made: 2 moderately warm and 2 cool phases occurred between 190000 and $150000 \mathrm{yr} \mathrm{BP}$; between ca 80000 and ca 33000 yr BP, 3 warm pulses, relative to the generally cooler conditions from 33000 to 11000 yr BP, are recorded.

\subsubsection{0 to 14000 yr BP}

Large areas around the south Tanganyika basin (773 m a.s.1.) were occupied by dry montane forest vegetation (Podocarpus, Olea, Juniperus and Ericaceae, today located above $1600 \mathrm{~m}$ ) from 25000 to 12000 yr BP, and the Zambezi woodlands were greatly reduced, with Brachystegia and some Euphorbiaceae as the main arboreal components, suggesting cool and dry climatic conditions (Vincens 1989b). In Lake Ishiba Ngandu, Zambia, a pollen record (Livingstone 1971) shows that the vegetation was characterised by grassland with Ericaceous elements, and some montane forest genera like Podocarpus, Olea and Myrica. Further south in the Wonderkrater sequence of northern Transvaal, a cold phase with an estimated temperature drop of 5 to $6^{\circ} \mathrm{C}$ is inferred to have occurred sometime between 25000 and 11000 yr BP (Scott 1990). The cold phase is associated with relatively humid climates, except for the coldest period, which corresponds with a dry spell (Scott 1990). In the upland grasslands of the eastern Orange Free State, more fynbos and swamps occurred under wet conditions at ca $23000 \mathrm{yr}$ BP, followed by slightly drier conditions between 22600 and $20000 \mathrm{yr} \mathrm{BP}$, then considerably drier and cooler climates from ca 20000 to 18000 yr BP (Scott 1990). In general, pollen evidence for this period shows that a considerable depression of vegetation belts occurred, displacing upland grasslands and shrublands to areas presently occupied by tropical savannah (Scott 1984, 1990).

\subsubsection{0 to 10000 yr BP}

In general, temperatures ameliorated and precipitation increased from about $14000 \mathrm{yr}$ BP in southern Africa (Scott et al. 1997). Montane forest communities around the south Tanganyika basin abruptly retreated at $12000 \mathrm{yr}$ BP, whereas the Zambezi woodlands greatly expanded and diversified (Vincens 1989b). These changes occur within the context of a climatic amelioration, primarily related to temperature increases (Vincens 1989a,b). Diatom analysis of a 40000 yr record from Lake Cheshi, Zambia, indicates that maximum shrinkage and chemical concentration of the lake occurred between 15000 and 13000 yr BP (Stager 1988). In the Transvaal bushveld, tropical savannah elements began increasing from 11000 yr BP (Scott 1990). There is no clear evidence of cooling in the pollen records of South Africa for the period 11000 to 10000 yr BP (the Younger Dryas), although oceanic cooling probably occurred off the coast of South Africa (Scott et al. 1995). The available data suggest that the Younger Dryas had no distinct counterpart in the inte- 
rior of southern Africa, or at least that an effect was not large enough to show up in the fossil pollen record (Scott et al. 1995).

\subsubsection{0 to $0 \mathrm{yr} \mathrm{BP}$}

Rainfall declined markedly in the early Holocene, but by 7000 yr BP, the biomes of southern Africa began to reflect modern conditions (Scott et al. 1997). Sediments from areas north of $28^{\circ} \mathrm{S}$ show prominent tropical woodland pollen, indicating that the period between 7000 and 6500 yr BP was associated with optimal temperatures during the Holocene (Scott 1993). Generally, the advent of moister conditions in southern Africa during the early to mid-Holocene is recorded earlier (7500 to $6500 \mathrm{yr} \mathrm{BP}$ ) in the north at ca $26^{\circ} \mathrm{S}$ than around $31^{\circ} \mathrm{S}$ (5000 yr BP), and this is provisionally associated with a relative shift in seasonality from a predominance of all-season precipitation to a greater proportion of summer rainfall (Scott 1993). The increase in tropical savannah elements in the Transvaal bushveld, from $11000 \mathrm{yr}$ BP through to $6500 \mathrm{yr}$ BP, suggests a gradual warming and drying (Scott 1990). A return to wetter conditions is marked by increasing prominence of Combretaceae and other broad-leaved savannah elements before 6500 yr BP, and related patterns of change have been found in the southern Kalahari (Scott 1990). The Namib desert was more grassy at ca $6500 \mathrm{yr} \mathrm{BP}$, and moister conditions at that time are supported by pollen data from hyrax middens from the Kuiseb river (Scott et al. 1997).

Holocene vegetation at Lake Ishiba Ngandu consisted of grassland with tropical woodland elements (Livingstone 1971). Lake Cheshi, Zambia, levels were exceptionally high between 8000 and 4000 yr BP (Stager 1988). Grassland has been the dominant vegetation on the Nyika plateau, Malawi, for the past $4500 \mathrm{yr}$, reflecting the contemporary vegetation pattern of small patches of montane forest in a sea of montane grassland (Meadows 1984). The driest part of the Holocene in southern Africa seems to have been the early Holocene. Particularly cool intervals in southern Africa occurred around 2800, 1600 and $300 \mathrm{yr}$ BP (Little Ice Age) (Lindesay 1998). Human impact on vegetation is recorded from about $1500 \mathrm{yr}$ BP (Scott et al. 1997).

\section{SUMMARY: TEMPORAL PROFILE OF VEGETATION CHANGE IN AFRICA}

Most vegetation records in Africa do not extend beyond $30000 \mathrm{yr}$ BP, except for a few from the humid tropics, such as Sacred Lake, Mount Kenya (Coetzee
1967, Street-Perrott et al. 1997, Olago et al. 1999), and Muchoya Swamp, Rukiga Highlands (Taylor 1990). Excluding the finer details unique to each site or region, there are broad generalisations that can be made for the period $30000 \mathrm{yr}$ BP to present.

From 30000 to 22000 yr BP, correlation of vegetation changes throughout the continent is not clear-cut; however, most sites are interpreted as having been cooler and less humid than at present. Highland vegetation was depressed to lower altitudes relative to their positions today, and grasslands became more widespread while lowland forests became increasingly fragmented in the humid tropics. These changes are primarily attributed to lower temperatures related to progressive global cooling. The last glacial maximum (LGM) period from 22000 to 14000 yr BP marks a time of high coherency in vegetation change throughout the African continent. This period, generally the coolest and most arid, marked the maximum depression and fragmentation of high altitude vegetation, maximum fragmentation of lowland forests, maximum extension of grasslands in the humid tropics, and maximum extension of the subtropical deserts. The period from 14000 to $10000 \mathrm{yr} \mathrm{BP}$ is viewed as a time of climatic amelioration, with rising temperatures and higher humidity. Depressed highland vegetation moved back up in altitude, lowland forests expanded, grasslands retreated, desert and semi-arid areas receded in spatial extent, etc. The record of these responses, however, are not well synchronised across the continent and are largely dependent on regional factors such as topography and aspect, and on the altitude and latitudes of the sites investigated. The maximum expression of humid vegetation types was manifested during the early Holocene, between 10000 and $8000 \mathrm{yr}$ BP, except in southern Africa, where it took place a little later. Drier conditions set in at about $4000 \mathrm{yr}$ BP in equatorial and northern Africa, and vegetation types and distribution established at that time remain so today.

The palaeovegetation changes in Africa have been attributed largely to changes in temperature, and secondarily to changes in precipitation. However, uncertainties still exist. For example, it has been noted that the estimates of tropical sea surface temperatures by CLIMAP (1981) and temperatures derived from adjacent land areas during the LGM are inconsistent $\left(2^{\circ} \mathrm{C}\right.$ vs 4 to $7^{\circ} \mathrm{C}$ respectively) (Rind \& Peteet 1985, Guilderson et al. 1994). The lower limits of the estimated temperature changes derived for East Africa recently using pollen transfer functions (e.g. Bonnefille et al. 1990, Vincens et al. 1993), however, do overlap with the upper limits of the CLIMAP (1981) temperature estimates, within the limits of uncertainty. Polar ice cores have, in addition, provided evidence of large 


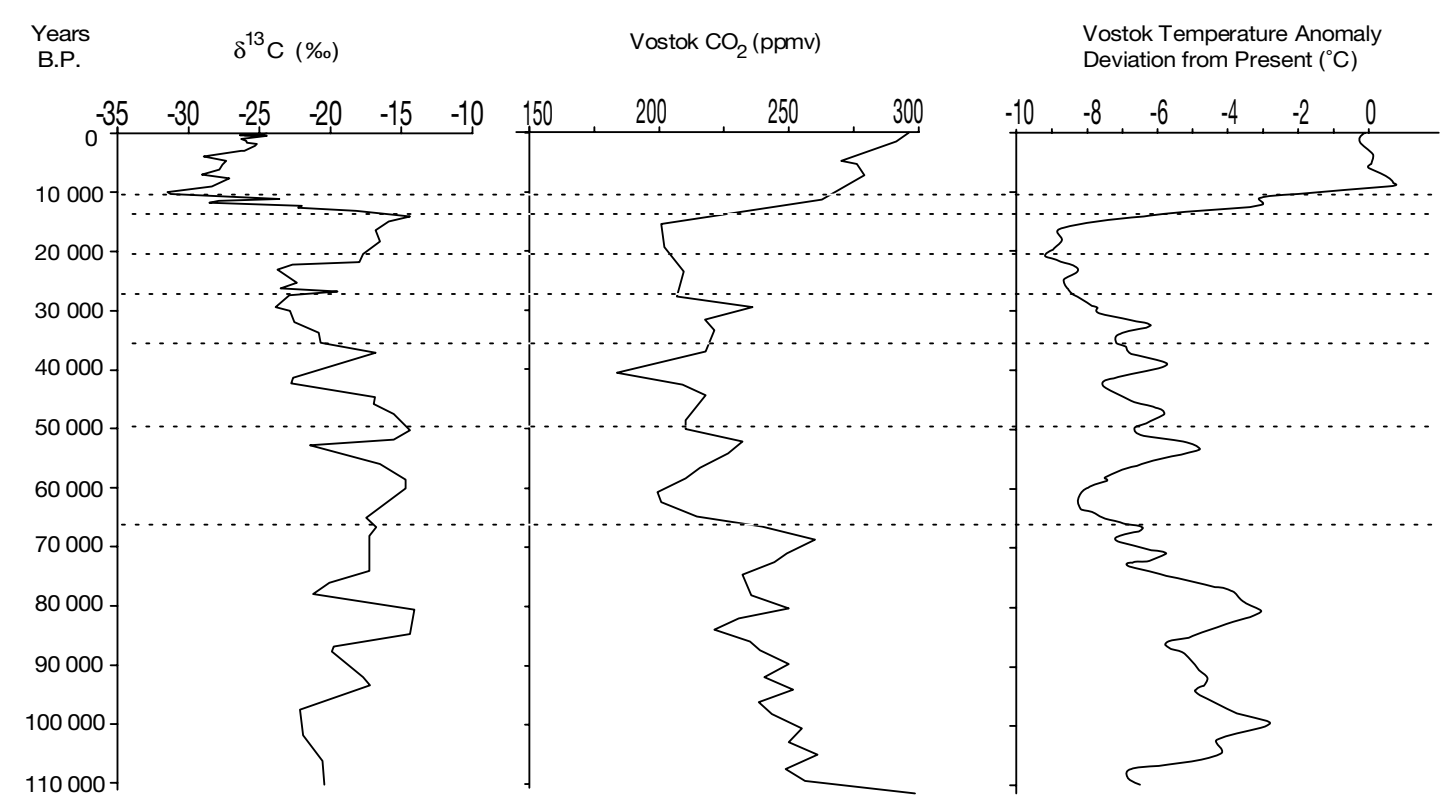

Fig. 6. Sacred Lake stable carbon isotope record versus Vostok ice core record

changes in the concentrations of the atmospheric greenhouse gases $\mathrm{CO}_{2}$ and $\mathrm{CH}_{4}$ through geological time (Delmas et al. 1980, Stauffer et al. 1984, Barnola et al. 1987, Chappellaz et al. 1990, Jouzel et al. 1993) extending back to 250000 yr ago in the case of the Vostok ice core (Jouzel et al. 1993). The gases vary in phase, and correlate well with temperature changes (Jouzel et al. 1993). Changes in the concentrations of these gases provide a strong climate feedback mechanism: Lorius et al. (1990) and Chappellaz et al. (1990) estimated that ca $50 \%$ of the Vostok temperature change over the last climate cycle may be accounted for by contributions from $\mathrm{CO}_{2}$ and $\mathrm{CH}_{4}$ (with a feedback factor of 3.5 owing to changes in atmospheric water vapour, clouds, and snow and ice cover) while most of the other $50 \%$ may be accounted for by the growth and decay of northern hemisphere ice sheets. Palaeoclimate modelling experiments (COHMAP Members 1988) also suggest that the changes in atmospheric $\mathrm{CO}_{2}$ and $\mathrm{CH}_{4}$ concentrations are sufficient to drive large variations in summer monsoon rainfall in the low latitude regions.

Fig. 6 shows the similarity of the bulk stable isotope values of the Sacred Lake profile and the Vostok ice core $\mathrm{CO}_{2}$ and temperature profiles. An elaborate explanation, arguing for changes in atmospheric $\mathrm{CO}_{2}$ contents as being the primary driver of vegetation change in the tropics, and not temperature as previously supposed, has been advanced, arising from re- sults obtained on bulk and compound-specific analysis of organic sediments from Sacred Lake and other supporting lines of evidence (Olago 1995, Huang et al. 1995, Street-Perrott et al. 1997, Olago et al. 1999). Periods of low precipitation/aridity tend to accentuate the effect of lower atmospheric $\mathrm{CO}_{2}$ (Olago 1995, Olago et al. 1999). These data suggest that temperature estimates for the last glacial maximum in the tropics are most probably too high, and that the role of precipitation changes in influencing vegetation dynamics is enhanced by low atmospheric $\mathrm{CO}_{2}$ concentrations. These conclusions are supported by results from a process based vegetation model simulating the response of montane vegetation in Kashiru, East Africa, to changes in atmospheric $\mathrm{CO}_{2}$ concentration and climate (Jolly \& Haxeltine 1997). On a longer time scale, the vegetation changes on Mount Kenya respond to the precessional cycle: the 23000 yr cycle is attributed largely to precessionally driven changes in atmospheric $\mathrm{CO}_{2}$ concentrations (Olago et al. 2000). Higher precessional harmonics are also evident: the $11500 \mathrm{yr}$ cycle (indicated by both mineral magnetics and $\delta^{13} \mathrm{C}$ trends) is related to the twice yearly passage of the sun across equatorial sites (Short et al. 1991), and thus reflects the effect of the seasonality of rainfall (twice yearly) on Mount Kenya (Olago et al. 2000). The data underline the importance of long-term orbital forcing and its impact on tropical vegetation through cyclic modulation of atmospheric trace gases and precipitation. 


\section{LITERATURE CITED}

Agwu COC, Beug HJ (1984) Palynologische Untersuchungen an marinen Sedimenten vor der westafrikanischen Küste. Palaeoecol Afr 16:37-52

Aucour A, Hillaire-Marcel C (1993) A 30,000 yr record of ${ }^{13} \mathrm{C}$ and ${ }^{18} \mathrm{O}$ changes in organic matter from an equatorial peatbog. In: Swart PK, Lohmann KC, McKenzie J, Savin S (eds) Climate change in continental isotopic records. Geophys Monogr 78:343-351

Aucour A, Hillaire-Marcel C, Bonnefille R (1994) Late Quaternary biomass changes from ${ }^{13} \mathrm{C}$ measurements in a highland peatbog from equatorial Africa (Burundi). Quat Res 41:225-233

Barnola JM, Raynaud D, Korotkevich YS, Louis C (1987) Vostok ice core provides 160,000 year record of atmospheric $\mathrm{CO}_{2}$. Nature 329:408-414

Barry RG, Chorley RJ (1992) Atmosphere, weather and climate. Routledge, London

Bonnefille R, Riollet G (1988) The Kashiru pollen sequence (Burundi) palaeoclimatic implications for the last 40,000 yr B.P. in tropical Africa. Quat Res 30:19-35

Bonnefille R, Roeland JC, Guiot J (1990) Temperature-rainfall estimates for the past 40,000 years in equatorial Africa. Nature 346:347-349

Brun A (1991) Reflexions sur les pluviaux et arides au Pléistocène supérieur et à l'Holocène en Tunisie. Palaeoecol Afr 22:157-170

Chappellaz J, Barnola JM, Raynaud D, Korotkevich YS, Lorius C (1990) Ice core record of atmospheric methane over the past 160,000 years. Nature 345:127-131

CLIMAP (1981) Seasonal reconstructions of the earth's surface at the last glacial maximum. Geol Soc Am Map Chart Ser MC-36

Coetzee JA (1967) Pollen analytical studies in East and Southern Africa. Palaeoecol Afr

COHMAP Members (1988) Climatic changes of the last 18,000 years: observations and model simulations. Science 241:1043-1052

Delmas RJ, Ascencio JM, Legrand M (1980) Polar ice evidence that atmospheric $\mathrm{CO}_{2} 20,000$ years BP was $50 \%$ of present. Nature 284:155-157

Flenley JR (1979a) The equatorial rain forest: a geological history. Butterworth and Co (Publishers) Ltd, London

Flenley JR (1979b) The late Quaternary vegetational history of the equatorial mountains. Prog Phys Geogr 3:488-509

Flohn H, Nicholson S (1980) Climatic fluctuations in the arid belt of the 'old world' since the last glacial maximum; possible causes and future implications. Palaeoecol Afr 12:3-22

Giresse P, Lanfranchi R (1984) Les climats et les oceans de la region Congolaise pendant l'Holocene-Bilans selons les échelles et les méthodes de l'observation. Palaeoecol Afr 16:77-88

Giresse P, Maley J, Brenac P (1994) Late Quaternary palaeoenvironments in the lake Barombi Mbo (West Cameroon) deduced from pollen and carbon isotopes of organic matter. Palaeogeogr Palaeoclimatol Palaeoecol 107:65-78

Guilderson TP, Fairbanks RG, Rubenstone JL (1994) Tropical temperature variations since 20,000 years ago: modulating inter-hemispheric climate change. Science 263:663-665

Hamilton AC (1972) The interpretation of pollen diagrams from Highland Uganda. Palaeoecol Afr 7:45-149

Hamilton AC (1982) Environmental history of East Africa; a study of the Quaternary. Academic Press, Hamilton

Hamilton AC (1987) Vegetation and climate of Mt. Elgon during late Pleistocene and Holocene. Palaeoecol Afr 18: 283-304
Hamilton AC, Perrott RA (1980) Modern pollen deposition on a tropical African mountain. Pollen Spores XXII(3-4): 438-468

Hamilton AC, Perrott RA (1981) A study of altitudinal zonation in the montane forest belt of Mt. Elgon, Kenya/ Uganda. Vegetatio 45:107-125

Hamilton A, Taylor D, Vogel JC (1986) Early forest clearance and environmental degradation in south-west Uganda. Nature 320:164-167

Hastenrath S (1984) The glaciers of equatorial East Africa. D. Reidel Publ Co, Dordrecht

Hastenrath S (1991) Climate dynamics of the tropics. Kluwer Academic Publishers, Dordrecht

Hastenrath S, Lamb HH (1979) Climatic atlas of the Indian Ocean, Vol 1. Surface climate and atmospheric circulation, Vol 2. The oceanic heat budget. University of Wisconsin Press, Madison, WI

Huang Y, Street-Perrott FA, Perrott RA, Eglinton G (1995) Molecular and carbon isotopic stratigraphy of a glacial/ interglacial sediment sequence from a tropical freshwater lake: Sacred Lake, Mt. Kenya. In: Grimalt JO, Dorronsorro $\mathrm{C}$ (eds) Organic geochemistry: developments and applications in energy, climate, environment and human history. AIGOA, Spain, p 826-829

Jackson SP (1961) Climatological atlas of Africa. Government Printer, Pretoria

Jolly D, Haxeltine A (1977) Effect of low glacial atmospheric $\mathrm{CO}_{2}$ on tropical African montane vegetation. Science 276: $786-788$

Jouzel J, Barkov NI, Barnola JM, Bender M, Chappellaz J, Genthon C, Kotlyakov VM, Lipenkov V, Lorius C, Petit JR, Raynaud D, Raisbeck G, Ritz C, Sowers T, Stievenard M, Yiou F, Yiou P (1993) Extending the Vostok ice-core record of palaeoclimate to the penultimate glacial period. Nature 364:407-412

Kendall RL (1969) An ecological history of the Lake Victoria Basin. Ecol Monogr 39:121-176

Lamb HF, van Der Kaars S (1995) Vegetational response to Holocene climatic change: pollen and palaeolimnological data from the Middle Atlas, Morocco. The Holocene 5(4): 400-408

Lamb HF, Eeicher U, Switsur VR (1989) An 18000 yr record of vegetation, lake level and climatic change from Tigalmamine, Middle Atlas, Morocco. J Biogeogr 16:65-74

Lamb HF, Gasse F, Benkaddour A, EL Hamouti N, van Der Kaars S, Perkins WT, Pearce NJ, Roberts CN (1995) Relation between century-scale Holocene arid intervals in tropical and temperate zones. Nature 373:134-137

Lézine AM (1982) Etude palynologique des sediments Quaternaires du Lac Abiyata (Ethiopie). Palaeoecol Afr 14: 93-98

Lézine AM (1989) Vegetational palaeoenvironments of northwest tropical Africa since 12,000 yr B.P: pollen analysis of continental sedimentary sequences (Senegal-Mauritania). Palaeoecol Afr 20:187-188

Lindesay J (1998) Past climates of southern Africa. In: Hobbs JE, Lindesay JA, Bridgman HA (eds) Climates of the southern continents: present, past and future. John Wiley and Sons, Chichester, p 161-206

Livingstone DA (1971) A 22,000-year pollen record from the plateau of Zambia. Limnol Oceanogr 16:349-356

Lorius C, Jouzel J, Raynaud D, Hansen JE, Le Treut H (1990) The ice core record: climate sensitivity and future greenhouse warming. Nature 347:139-145

Maitima JM (1988) History of vegetation in the Central Rift Valley, Kenya. MSc thesis, Duke University, Durham, NC Maitima JM (1991) Vegetation response to climatic change in 
Central Rift Valley, Kenya. Quat Res 35:234-245

Maley J (1987) Fragmentation de la forêt dense humide Africaine et extension des biotopes montagnards au Quaternaire recent: nouvelles données polliniques et chronologiques. Implication palaéoclimatiques et biogéographiques. Palaeoecol Afr 18:307-336

Maley J (1992) Mise en évidence d'une péjoration climatique entre ca. 2,500 et 2,000 ans B.P. en Afrique tropicale humide. Bull Soc Géol Fr 3:363-365

Meadows ME (1984) Late Quaternary vegetation history of the Nyika Plateau, Malawi. J Biogeogr 11:209-222

Morrison MES (1968) Vegetation and climate in the uplands of south-western Uganda during the later Pleistocene Period, I. Muchoya Swamp, Kigezi District. J Ecol 56:363-384

Neumann K (1991) In search for the green Sahara: palynology and botanical remains. Palaeoecol Afr 22:203-212

Ogallo LJ (1989) The spatial and temporal patterns of the East African seasonal rainfall derived from principal components analysis. Int J Climatol 9:145-167

Olago DO (1995) Late Quaternary lake sediments of Mount Kenya, Kenya. DPhil thesis, University of Oxford

Olago DO, Street-Perrott FA, Perrott RA, Ivanovich M, Harkness DD (1999) Late Quaternary glacial-interglacial cycle of climatic and environmental change on Mount Kenya, Kenya. J Afr Earth Sci 29(2):1-26

Olago DO, Odada EO, Street-Perrott FA, Perrott RA, Ivanovich M, Harkness DD (2000) Long-term temporal characteristics of palaeomonsoon dynamics in equatorial Africa. Global Planet Change 26(1-3):159-171

Owen RB, Barthelme JW, Renaut RW, Vincens A (1982) Palaeolimnology and archaeology of Holocene deposits north-east of Lake Turkana, Kenya. Nature 298:523-529

Perrott RA (1982a) A high altitude pollen diagram from Mount Kenya: its implications for the history of glaciation. Palaeoecol Afr 14:77-83

Perrott RA (1982b) A postglacial pollen record from Mount Satima, Aberdare Range, Kenya. In: Am Quat Assoc 7th Biennial Conference Seattle, June 1982. Program and Abstracts

Perrott RA, Street-Perrott FA (1982) New evidence for a late Pleistocene wet phase in northern intertropical Africa. Palaeoecol Afr 14:57-75

Rind D, Peteet D (1985) Terrestrial conditions at the Last Glacial Maximum and CLIMAP sea-surface temperature estimates: are they consistent? Quat Res 24:1-22

Roche E, Bikwemu G (1989) Palaeoenvironmental change on the Zaire-Nile ridge in Burundi; the last 2000 years: an interpretation of palynological data from the Kashiru Core, Ijenda, Burundi. In: Mahaney WC (ed) Quaternary environmental research on East African mountains. Balkema, Rotterdam, p 231-244

Scott L (1984) Palynological evidence for Quaternary palaeoenvironments in southern Africa. In: Klein RG (ed) Southern African palaeoenvironments and pre-history. Balkema, Rotterdam, p 65-80

Scott L (1990) Palynological evidence for late Quaternary environmental change in southern Africa. Palaeoecol Afr 21:259-268

Scott L (1993) Palynological evidence for late Quaternary warming episodes in southern Africa. Palaeogeogr Palaeoecol Palaeoclimatol 101:229-235

Scott L (1999) Vegetation history and climate in the savannah biome South Africa since 190,000 ka: a comparison of pollen data from the Tswaing Crater (the Pretoria Saltpan) and Wonderkrater. Quat Int 57/58:215-223

Scott L, Steenkamp M, Beaumont PB (1995) Palaeoenviron- mental conditions in South Africa at the PleistoceneHolocene transition. Quat Sci Rev 14:937-947

Scott L, Anderson HM, Anderson JM (1997) Vegetation history. In: Cowling RM, Richardson DM, Pierce SM (eds) Vegetation of southern Africa. Cambridge University Press, Cambridge, p 62-84

Short DA, Mengel JG, Crowley TJ, Hyde WT, North GR (1991) Filtering of Milankovitch cycles by earth's geography. J Quaternary Res 35:157-173

Sowunmi MA (1981) Nigerian vegetational history from the late Quaternary to the present day. Palaeoecol Afr 13: $217-234$

Stager JC (1988) Environmental changes at Lake Cheshi, Zambia since 40, 000 years B.P. Quat Res 29:54-65

Stauffer B, Hofer H, Oeschger J, Schwander J, Siegenthaler U (1984) Atmospheric $\mathrm{CO}_{2}$ concentration during the last glaciation. Ann Glaciol 5:160-164

Street-Perrott FA, Perrott RA (1993) Holocene vegetation, lake levels and climate of Africa. In: Wright HE, Kutzbach JE, Webb T III, Ruddiman WF, Street-Perrott FA, Bartlein PJ (eds) Global climates since the last glacial maximum. University of Minnesota Press, Minneapolis, p 318-356

Street-Perrott FA, Huang Y, Perrott RA, Eglinton G, Barker P, Khelifa L, Harkness DD, Olago DO (1997) Impact of lower atmospheric carbon dioxide on tropical mountain ecosystems. Science 278:1422-1426

Talbot MR, Hall JB (1981) Further late Quaternary leaf fossils from Lake Bosumtwi, Ghana. Palaeoecol Afr 13:83-92

Talbot MR, Johannessen T (1992) A high resolution palaeoclimatic record for the last 27,500 years in tropical west Africa from the carbon and nitrogen isotopic composition of lacustrine organic matter. Earth Planet Sci Lett 100:23-37

Talbot MR, Livingstone DA, Palmer PG, Maley J, Melack JM, Delibrias G, Gulliksen S (1984) Preliminary results from sediment cores from Lake Bosumtwi, Ghana. Palaeoecol Afr 16:173-192

Taylor DM (1990) Late Quaternary pollen records from two Ugandan mires: evidence for environmental change in the Rukiga Highlands of southwest Uganda. Palaeogeogr Palaeoclimatol Palaeoecol 80:283-300

Thompson BW (1965) The climate of Africa. Oxford University Press, Nairobi

van Zinderen Bakker EM Sr (1980) Comparison of late Quaternary climatic evolutions in the Sahara and the NamibKalahari region. Palaeoecol Africa 12:381-394

van Zinderen Bakker EM Sr, Coetzee JA (1972) A reappraisal of late Quaternary climatic evidence from tropical Africa. Palaeoecol Afr 7:151-182

Vincens A (1986) Diagramme pollinique d'un sondage Pleistocene supérieur-Holocene du Lac Bogoria (Kenya). Rev Palaeobot Palynol 47:162-192

Vincens A (1989a) Palaeoenvironments du bassin nordTanganyika (Zaïre, Burundi, Tanzanie) au cours des 13 derniers milles ans: apport de la palynologie. Rev Palaeobot Palynol 61:69-88

Vincens A (1989b) Les forêts zambéziennes du bassin SudTanganyika. Evolution entre 25,000 et 6,000 ans B.P. CR Acad Sci Paris 308 Sér II: 809-814

Vincens A (1989c) Early Holocene pollen data from an arid East African region, Lake Turkana, Kenya: botanical and climatic implications. Palaeoecol Afr 20:87-97

Vincens A, Chalié F, Bonnefille R, Guiot J, Tiercelin JJ (1993) Pollen-derived rainfall and temperature estimates for Lake Tanganyika and their implication for late Pleistocene water levels. Quat Res 40:343-350

White F (1983) The vegetation of Africa. UNESCO, Paris 